\title{
Evaluation of farmer awareness on rubber cultivation and production technologies in major rubber-growing areas of Sri Lanka
}

\author{
D.M.A.P. Dissanayake ${ }^{1^{*}}$, P.K.K.S. Gunaratne ${ }^{1}$ and W. Wijesuriya ${ }^{2}$
}

\begin{abstract}
The study focused on 23 sites representing traditional rubber growing areas of Kegalle, Ratnapura, Kalutara, Galle, Matara and Colombo districts in Sri Lanka. Methodology employed in the study was mainly participatory in nature with 1828 farmers. Questions to test awareness were categorized under recommendations in (a) agronomic practices, (b) tapping-related activities and (c) processing aspects of sheet rubber. The questions were displayed to farmers and they were given a chance to select the answer and vote for it. Awareness score was devised by calculating the \% of correct answers for each question. Cluster analysis was employed to categorize different locations. Awareness on agronomic recommendations in different sites ranged from 28 $\%$ to $62 \%$. The overall awareness on tapping ranged from $34 \%$ to $62 \%$. Awareness scores for processing of sheet rubber ranged from $16 \%$ to $42 \%$ and indicated poor awareness on processing among smallholder farmers. The study identified similar groups from sites in the districts based on awareness of recommendations under immature phase, tapping and processing activities. The paper suggests spatial priorities for technology transfer in the smallholder sector to improve adoption of recommendations.
\end{abstract}

Keywords: Rubber, smallholder, awareness, technology transfer

\section{Introduction}

Rubber is traditionally grown in nine districts in the Western, Sambaragamuwa, Southern and Central provinces in Sri Lanka (Anonymous, 2012), and found under estate and smallholder sectors. The smallholder sector covers lands usually less than four ha in extent. Considerable attempts have been made to improve productivity in the smallholder sector, yet it is producing under 1500 $\mathrm{kg} / \mathrm{ha} /$ year, which is well below the productivity values recorded in other producing countries. Although improved clones are introduced to the farmers, poor adoption of recommended technologies has hindered attaining the potential yields of these clones. Inadequate knowledge of farmers on technologies has been identified in several studies as adversely affecting their adoption (Wijesuriya et al., 2005, 2006, 2007, 2008). Efficient technology transfer is one of the best solutions to improve adoption of new technologies in the rubber sector (Dissanayake, 2009). Devising such technology transfer

\footnotetext{
${ }^{1}$ Rubber Research Institute of Sri Lanka, Telewala Road, Ratmalana, Sri Lanka

${ }^{2}$ Rubber Research Institute of Sri Lanka, Dartonfield, Agalawatta, Sri Lanka

* Corresponding Author: anurapd@gmail.com
} 
methods is a task, which needs strategic planning. Prior information on "awareness", the extent to which the farmers are known/heard of innovations, is of immense importance in devising and prioritizing demand-driven extension programmes for different areas.

The Advisory Services Department (ASD) is the extension arm of the Rubber Research Institute of Sri Lanka (RRISL), and has the primary responsibility of disseminating scientific information and technologies especially to the smallholder rubber sector. The ASD has launched numerous activities through various extension approaches to fulfill the extension needs of the smallholder sector. The dissemination process can be further improved by prioritizing the programmes with respect to locations and the content. A study conducted in non-traditional rubber growing areas has identified the priority areas, which has been used successfully in technology transfer programmes (Wijesuriya et al., 2010). A considerable saving on time and costs also can be envisaged through this process. Hence, this study was conducted with the objectives to assess the awareness of rubber farmers on recommended technologies in major rubber growing areas and to take prioritized action based on locations and contents in rendering extension services.

\section{Methodology}

\section{Description of the study area}

The study covered six districts, and one site each from 23 Divisional Secretariat (DS) divisions (Table 1). A total of 1828 rubber smallholders were involved in the study, which was conducted throughout 2013 under both categories of immature and mature phases.

\section{Data collection}

The study employed a participatory research tool termed, 'Pocket voting' for testing awareness on recommendations. In this exercise, the farmers read questions one by one and selected the answer and then voted for it by inserting a small card to the relevant envelope. The recommendations were categorized into (a) agronomic, (b) tapping and (c) processing of smoked sheets. The questions under each category were listed under three broad headings (Tables 2, 3 and 4). The questions were displayed in local language with simple illustrations and wordings. For each question, the correct answers were counted and awareness on recommendations was calculated as a percentage.

\section{Analysis of data}

The awareness scores were generated for recommendations on agronomic, tapping-related and processing aspects for different sites through the participatory study on testing of awareness on recommendations. They were 
used in statistical analysis. The statistical method employed was agglomerative hierarchical approach in cluster analysis as it is the most widely used method compared to divisive method (Rencher, 2002). The statistical software, Genstat ver. 16 was used in data analysis.

Table 1. Study sites in different DS divisions

\begin{tabular}{|c|c|c|c|}
\hline District & DS division & Village & No. of participants \\
\hline Colombo & Kosgama & Kosgama & 69 \\
\hline \multirow[t]{8}{*}{ Kegalle } & Mawanella & Sinharajagama & 76 \\
\hline & Warakapola & Malmaduwa & 64 \\
\hline & Rambukkana & Rambukkana & 91 \\
\hline & Yatiyantota & Ambuwakka & 120 \\
\hline & Warakapola & Ranapana & 66 \\
\hline & Ruwanwella & Indurana & 104 \\
\hline & Kegalle & Dikella & 58 \\
\hline & Dehiovita & Maniangamuwa & 50 \\
\hline \multirow[t]{5}{*}{ Ratnapura } & Eheliyagoda & Erepola & 58 \\
\hline & Ratnapura & Gilimale & 84 \\
\hline & Nivitigala & Nivitigala & 61 \\
\hline & Kalawana & Karavita & 108 \\
\hline & Kuruvita & Pahalapohorabawa & 57 \\
\hline Galle & Galle & Thalawa & 117 \\
\hline \multirow[t]{2}{*}{ Matara } & Akuressa & Akuressa & 178 \\
\hline & Hakmana & Hakmana & 96 \\
\hline \multirow[t]{7}{*}{ Kalutara } & Horana & Gatakossawa & 55 \\
\hline & Bulatsinhala & Dewamulla & 59 \\
\hline & Agalawatta & Hedigalle & 66 \\
\hline & Millaniya & Haltota & 98 \\
\hline & Matugama & Katugahahena & 60 \\
\hline & Kalutara & Hembarawila & 33 \\
\hline & & Total & 1828 \\
\hline
\end{tabular}

\section{Analysis of data}

The awareness scores were generated for recommendations on agronomic, tapping-related and processing aspects for different sites through the participatory study on testing of awareness on recommendations. They were used in statistical analysis. The statistical method employed was agglomerative hierarchical approach in cluster analysis as it is the most widely used method compared to divisive method (Rencher, 2002). The statistical software, Genstat ver. 16 was used in data analysis. 
Table 2. Questions tested for awareness on agronomic recommendations.

\begin{tabular}{|c|c|}
\hline Category & Tested areas of awareness \\
\hline Planting-related activities & $\begin{array}{ll}\text { 1. } & \text { Measures to be taken up in replanting } \\
\text { 2. } & \text { Recommended clones for smallholders } \\
\text { 3. } & \text { Recommended trees per ha. } \\
\text { 4. } & \text { Recommended spacing } \\
\text { 5. System of planting in a slopy area } \\
\text { 6. Recommended Size of planting hole } \\
\text { 7. Main reason for elephant foot formation in } \\
\text { trunk }\end{array}$ \\
\hline Intercropping & $\begin{array}{l}\text { 1. Correct spacing for rubber with intercrops } \\
\text { 2. Types of intercrops used under rubber }\end{array}$ \\
\hline Diseases/Disorders & $\begin{array}{l}\text { 1. Treatment for white root disease } \\
\text { 2. Reasons for tapping panel dryness (TPD) }\end{array}$ \\
\hline Soil fertility management & $\begin{array}{l}\text { 1. Application of urea based mixture with } \\
\text { dolomite } \\
\text { 2. Fertilizer application for mature rubber } \\
\text { 3. Method of fertilizer application } \\
\text { 4. Soil conservation in a slopy land } \\
\text { 5. Soil fertility \& ground cover management }\end{array}$ \\
\hline
\end{tabular}

Table 3. Questions tested for awareness on recommendations related to tapping.

\begin{tabular}{|c|c|}
\hline Category & Tested areas of awareness \\
\hline General awareness on tapping & $\begin{array}{l}\text { 1. Required number of tappable trees to } \\
\text { commence tapping } \\
\text { 2. Required girth at tapping \& height of } \\
\text { measurement } \\
\text { 3. Cup hanging } \\
\text { 4. Time of tapping } \\
\text { 5. Sharpening of tapping knife }\end{array}$ \\
\hline Technical awareness on tapping & $\begin{array}{l}\text { 1. Height of tapping panel } \\
\text { 2. Angle of tapping } \\
\text { 3. Tapping panel marking } \\
\text { 4. Tapping system } \\
\text { 5. Depth of tapping } \\
\text { 6. Thickness of tapping } \\
\text { 7. Frequency of tapping for new clones }\end{array}$ \\
\hline
\end{tabular}


Table 4. Questions tested for awareness on recommendations related to processing of smoked sheets

\begin{tabular}{lll}
\hline Category & & \multicolumn{1}{c}{ Tested areas of awareness } \\
\hline Initial processing & 1. & Removal of pigments in latex \\
activities & 2. & Reasons for pre coagulation \\
& 3. & Acids \& their concentration for coagulation \\
& 4. & Dilution of formic acid \\
Secondary & & \\
processing & 1. & Diluted acid requirement for a standard sheet \\
activities & 2. & Latex straining \\
& 3. & Latex and water ratio for a standard sheet \\
& 4. & Diluted latex requirement per coagulating tray \\
Rolling of sheets & 5. & Measures to be taken up after addition of acids \\
& 1. & Advantage of rolling in the diamond roller \\
Smoking \& drying & 2. & Measures to be taken up after rolling in the diamond roller \\
& 3. & Measures to be taken up after completion of rolling \\
& 1. & Recommended temperature inside the smoke house \\
& 2. & Recommended structure for the ceiling \\
3. & Ventilation holes in a smoke house \\
Sheet production - & 4. & Types of fuel used for sheet drying \\
grading & 1. & Standard dimensions of a rubber sheet \\
& 2. & Weight of a rubber sheet \\
& 3. & Reason for tackiness in sheets \\
4. & Grading of rubber sheets
\end{tabular}

\section{Results and Discussion}

\section{Awareness on agronomic recommendations}

The awareness scores of different agronomic recommendations in the villages are listed in Table 5. The average overall awareness on these recommendations was $49 \%$ with a range of $28 \%$ to $62 \%$. Awareness on four activities viz. plantingrelated activities, intercropping, soil fertility management and disorders, and disease control, were moderate with averages of $46 \%, 45 \%, 62 \%$ and $45 \%$, respectively, in the selected villages.

Based on the cluster analysis of awareness scores for different activities in selected sites, three homogenous groups (I, II, III) were found as depicted in Figure 2. Group I, II and III had two, seven and 14 villages, respectively, with average scores of $28 \%, 45 \%$ and $55 \%$. Group I, II and III can be ranked according to the priority of awareness raising activities viz. high to low. There were two villages with poor awareness of $28 \%$ in the DS divisions, Kosgama in Colombo 
district and Dehiovita in Kegalle district, which need priority actions to improve awareness.

Table 5. Awareness on different agronomic practices in different villages

\begin{tabular}{|c|c|c|c|c|c|c|c|}
\hline \multirow{2}{*}{ District } & \multirow{2}{*}{ DS division } & \multirow{2}{*}{ Village } & \multicolumn{4}{|c|}{ \% awareness* } & \multirow{2}{*}{$\begin{array}{c}\text { Overall } \\
\text { awareness }\end{array}$} \\
\hline & & & $A$ & $B$ & $C$ & $\mathrm{D}$ & \\
\hline Colombo & Kosgama & Kosgama & 18 & 32 & 45 & 17 & 28 \\
\hline \multirow[t]{8}{*}{ Kegalle } & Mawanella & Sinharajagama & 50 & 55 & 68 & 31 & 51 \\
\hline & Warakapola & Malmaduwa & 55 & 48 & 63 & 55 & 55 \\
\hline & Rambukkana & Rambukkana & 56 & 53 & 61 & 50 & 55 \\
\hline & Yatiyantota & Ambuwakka & 55 & 68 & 72 & 55 & 62 \\
\hline & Warakapola & Ranapana & 35 & 27 & 67 & 49 & 44 \\
\hline & Ruwanwella & Indurana & 56 & 50 & 59 & 52 & 54 \\
\hline & Kegalle & Dikella & 32 & 34 & 67 & 56 & 47 \\
\hline & Dehiovita & Maniangamuwa & 26 & 27 & 24 & 33 & 28 \\
\hline \multirow[t]{5}{*}{ Ratnapura } & Eheliyagoda & Erepola & 53 & 28 & 56 & 28 & 41 \\
\hline & Ratnapura & Gilimale & 52 & 59 & 60 & 48 & 55 \\
\hline & Nivitigala & Nivitigala & 47 & 51 & 67 & 50 & 53 \\
\hline & Kalawana & Karavita & 40 & 48 & 67 & 52 & 52 \\
\hline & Kuruvita & $\begin{array}{l}\text { Pahala- } \\
\text { pohorabawa }\end{array}$ & 41 & 42 & 49 & 45 & 44 \\
\hline Galle & Galle & Thalawa & 35 & 57 & 52 & 40 & 46 \\
\hline \multirow[t]{2}{*}{ Matara } & Akuressa & Akuressa & 70 & 64 & 62 & 37 & 58 \\
\hline & Hakmana & Hakmana & 44 & 29 & 62 & 43 & 44 \\
\hline \multirow[t]{9}{*}{ Kalutara } & Horana & Gatakossawa & 50 & 44 & 68 & 54 & 54 \\
\hline & Bulatsinhala & Dewamulla & 57 & 45 & 79 & 43 & 56 \\
\hline & Agalawatta & Hedigalle & 53 & 46 & 58 & 45 & 50 \\
\hline & Millaniya & Haltota & 53 & 45 & 76 & 60 & 58 \\
\hline & Matugama & Katugahahena & 34 & 36 & 72 & 48 & 47 \\
\hline & Kalutara & Hembarawila & 39 & 44 & 73 & 49 & 51 \\
\hline & & Average & 46 & 45 & 62 & 45 & 49 \\
\hline & & Min & 18 & 27 & 24 & 17 & 28 \\
\hline & & Max & 70 & 68 & 79 & 60 & 62 \\
\hline
\end{tabular}

A - Planting-related activities, B - Inter cropping, C - Soil fertility management, D Disorders and disease control 


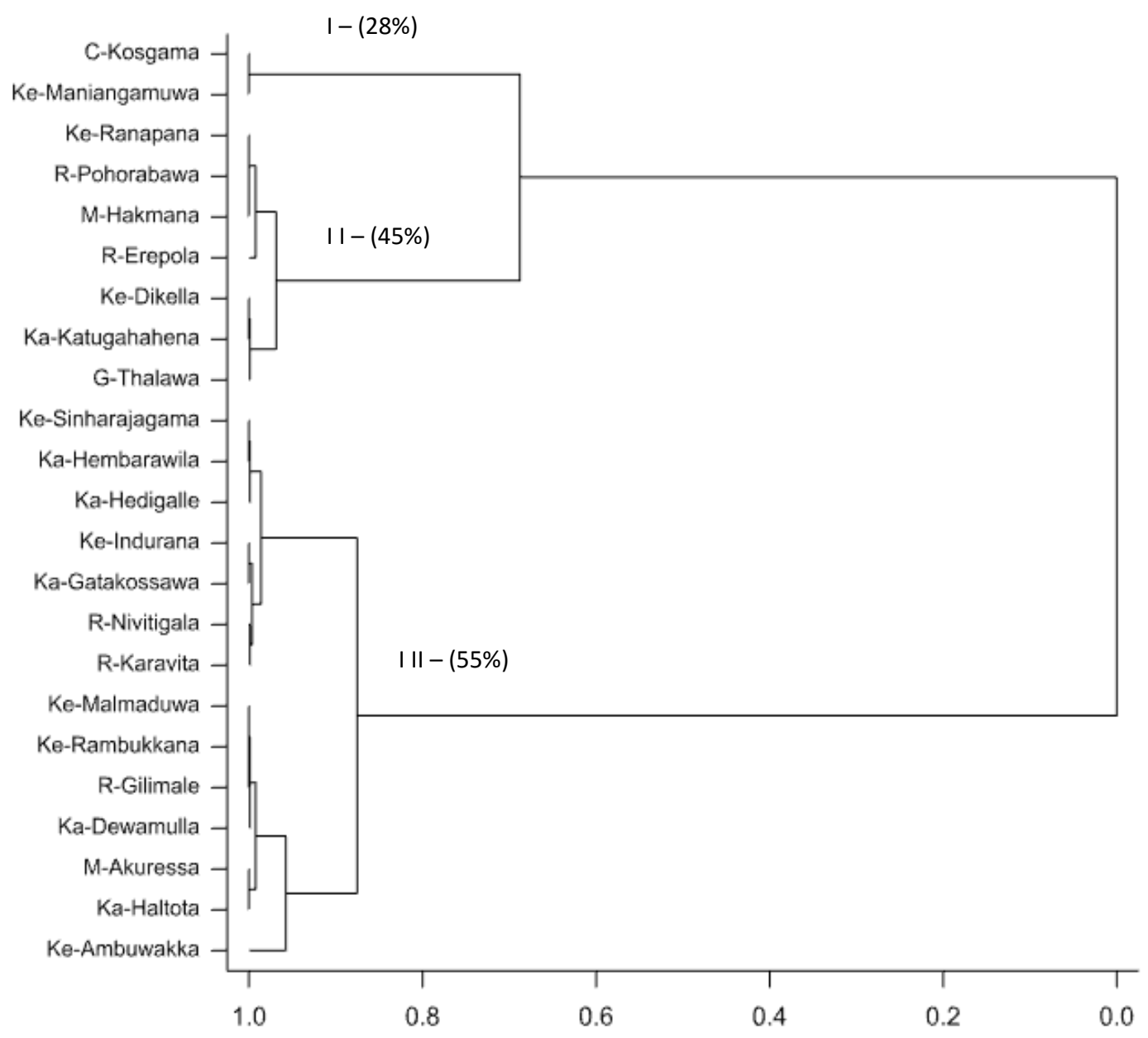

Figure 2. Dendrogram showing successive fusion of villages based on awareness on agronomic recommendations

\section{Awareness on recommendations on tapping-related activities}

Awareness scores of general and technical knowledge on tapping generated through questions listed in Table 3 in different villages are presented in Table 6. The awareness on tapping-related activities is not adequate i.e. the average awareness scores for both general and technical knowledge on tapping were nearly $50 \%$. As depicted in Figure 3, three homogenous groups (I , II and III) can be found with the average scores of $39 \%, 50 \%$ and $58 \%$. All these groups can be named as 'Moderate' according to the awareness on the recommendations on tapping-related activities. Yet priority should be first placed on Group I, which has an average of $39 \%$ that consisted of five villages in DS divisions Kosgama, 
Dehiovita, Eheliyagoda, Galle and Akuressa, in Colombo, Kegalle, Ratnapura, Galle and Matara districts, respectively. The other groups (II and III) consisted of 10 and eight villages, respectively (Figure 3).

Table 6. Awareness on general and technical knowledge on tapping

\begin{tabular}{|c|c|c|c|c|c|}
\hline \multirow{2}{*}{ District } & \multirow{2}{*}{ DS division } & \multirow{2}{*}{ Village } & \multicolumn{2}{|c|}{$\%$ awareness* } & \multirow{2}{*}{$\begin{array}{c}\text { Overall } \\
\text { awareness }\end{array}$} \\
\hline & & & $A$ & $B$ & \\
\hline Colombo & Kosgama & Kosgama & 41 & 40 & 41 \\
\hline \multirow[t]{8}{*}{ Kegalle } & Mawanella & Sinharajagama & 50 & 49 & 50 \\
\hline & Warakapola & Malmaduwa & 61 & 51 & 56 \\
\hline & Rambukkana & Rambukkana & 60 & 53 & 57 \\
\hline & Yatiyantota & Ambuwakka & 52 & 43 & 47 \\
\hline & Warakapola & Ranapana & 54 & 46 & 50 \\
\hline & Ruwanwella & Indurana & 65 & 53 & 59 \\
\hline & Kegalle & Dikella & 60 & 53 & 57 \\
\hline & Dehiovita & Maniangamuwa & 33 & 34 & 34 \\
\hline \multirow[t]{5}{*}{ Ratnapura } & Eheliyagoda & Erepola & 38 & 43 & 40 \\
\hline & Ratnapura & Gilimale & 54 & 45 & 49 \\
\hline & Nivitigala & Nivitigala & 56 & 47 & 51 \\
\hline & Kalawana & Karavita & 68 & 57 & 62 \\
\hline & Kuruvita & Pahala-pohorabawa & 49 & 45 & 47 \\
\hline Galle & Galle & Thalawa & 37 & 36 & 36 \\
\hline \multirow[t]{2}{*}{ Matara } & Akuressa & Akuressa & 43 & 41 & 42 \\
\hline & Hakmana & Hakmana & 56 & 48 & 52 \\
\hline \multirow[t]{9}{*}{ Kalutara } & Horana & Gatakossawa & 60 & 54 & 57 \\
\hline & Bulatsinhala & Dewamulla & 64 & 55 & 60 \\
\hline & Agalawatta & Hadigalle & 54 & 48 & 51 \\
\hline & Millaniya & Haltota & 62 & 52 & 57 \\
\hline & Matugama & Katugahahena & 59 & 48 & 53 \\
\hline & Kalutara & Hembarawila & 56 & 49 & 52 \\
\hline & & Average & 53 & 47 & 50 \\
\hline & & Min & 33 & 34 & 34 \\
\hline & & Max & 68 & 57 & 62 \\
\hline
\end{tabular}

* A - General knowledge on tapping, B - Technical knowledge on tapping

\section{Awareness on recommendations on processing-related activities}

The average awareness scores for processing-related activities were $32 \%$ (Table 7) indicating poor awareness, which needs attention in technology transfer 
programmes in all villages. Three homogenous groups (I, II \& III) were found with average scores $23 \%$, of $32 \%$ and $39 \%$ (Figure 4). Among the five activities considered for awareness testing, the poorest area was secondary processing activities (Table 4) with awareness scores ranged from $0 \%$ to $16 \%$ Immediate action on improving awareness is needed in DS divisions; Ratnapura, Galle, Agalawatta and Dehiowita in respective districts, Ratnapura, Galle, Kalutara and Kegalle.

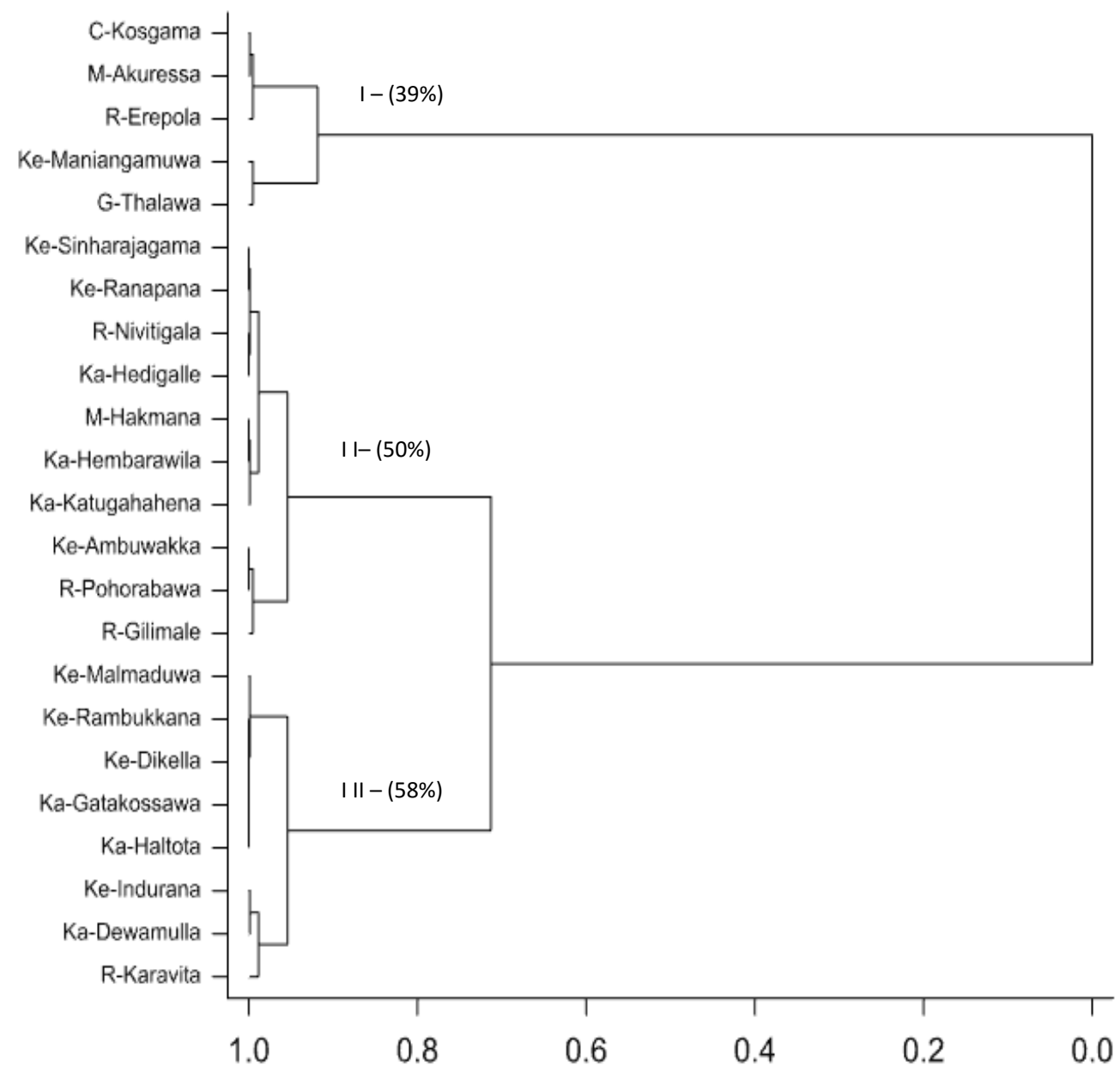

Figure 3. Dendrogram showing successive fusion of villages based on awareness on tapping-related activities.

\section{Priorities for technology transfer}

The priorities for technology transfer (Table 8 ) could be identified based on the analysis of awareness scores for different technologies falling into agronomic 
operations, tapping and processing activities of rubber cultivation. In generalthe level of awareness for recommendations falling into agronomic operations, tapping and processing has not reached the satisfactory level. Hence, although priorities were identified, awareness raising in the rest of the locations is also important to improve the productivity of smallholder rubber lands

Table 7. Awareness on processing-related activities

\begin{tabular}{|c|c|c|c|c|c|c|c|c|}
\hline \multirow{2}{*}{ District } & \multirow{2}{*}{ DS division } & \multirow{2}{*}{ Village } & \multicolumn{5}{|c|}{$\%$ awareness* } & \multirow{2}{*}{$\begin{array}{c}\text { Overall } \\
\text { awareness }\end{array}$} \\
\hline & & & A & $\mathrm{B}$ & $\mathrm{C}$ & $\mathrm{D}$ & $E$ & \\
\hline Colombo & Kosgama & Kosgama & 34 & 11 & 47 & 45 & 34 & 34 \\
\hline \multirow[t]{8}{*}{ Kegalle } & Mawanella & Sinharajagama & 38 & 14 & 49 & 25 & 44 & 34 \\
\hline & Warakapola & Malmaduwa & 19 & 15 & 38 & 30 & 61 & 32 \\
\hline & Rambukkana & Rambukkana & 30 & 3 & 27 & 33 & 57 & 30 \\
\hline & Yatiyantota & Ambuwakka & 27 & 15 & 40 & 43 & 62 & 37 \\
\hline & Warakapola & Ranapana & 27 & 1 & 33 & 29 & 55 & 29 \\
\hline & Ruwanwella & Indurana & 32 & 16 & 36 & 23 & 50 & 31 \\
\hline & Kegalle & Dikella & 31 & 10 & 40 & 40 & 51 & 34 \\
\hline & Dehiovita & Maniangamuwa & 14 & 7 & 19 & 15 & 26 & 16 \\
\hline \multirow[t]{5}{*}{ Ratnapura } & Ehaliyagoda & Erepola & 31 & 15 & 45 & 39 & 44 & 35 \\
\hline & Ratnapura & Gilimale & 16 & 4 & 24 & 29 & 41 & 23 \\
\hline & Nivitigala & Nivitigala & 25 & 9 & 31 & 30 & 49 & 29 \\
\hline & Kalawana & Karavita & 26 & 16 & 45 & 36 & 56 & 36 \\
\hline & Kuruvita & Pahala-pohorabawa & 23 & 12 & 34 & 25 & 57 & 30 \\
\hline Galle & Galle & Thalawa & 28 & 14 & 34 & 22 & 36 & 27 \\
\hline \multirow[t]{2}{*}{ Matara } & Akuressa & Akuressa & 52 & 0 & 34 & 39 & 43 & 34 \\
\hline & Hakmana & Hakmana & 45 & 12 & 38 & 34 & 64 & 38 \\
\hline \multirow[t]{9}{*}{ Kalutara } & Horana & Gatakossawa & 34 & 16 & 48 & 52 & 60 & 42 \\
\hline & Bulatsinhala & Dewamulla & 33 & 13 & 47 & 26 & 64 & 37 \\
\hline & Agalawatta & Hedigalle & 26 & 12 & 31 & 15 & 43 & 25 \\
\hline & Millaniya & Haltota & 36 & 14 & 45 & 42 & 56 & 39 \\
\hline & Matugama & Katugahahena & 31 & 13 & 40 & 38 & 52 & 35 \\
\hline & Kalutara & Hembarawila & 28 & 10 & 37 & 28 & 62 & 33 \\
\hline & & Average & 30 & 11 & 38 & 32 & 51 & 32 \\
\hline & & Min & 14 & 0 & 19 & 15 & 26 & 16 \\
\hline & & $\operatorname{Max}$ & 52 & 16 & 49 & 52 & 64 & 42 \\
\hline
\end{tabular}

* A - Initial processing activities, B - Secondary processing activities, C - Rolling of sheets, D - Smoking and drying and E - Standards and Grading 


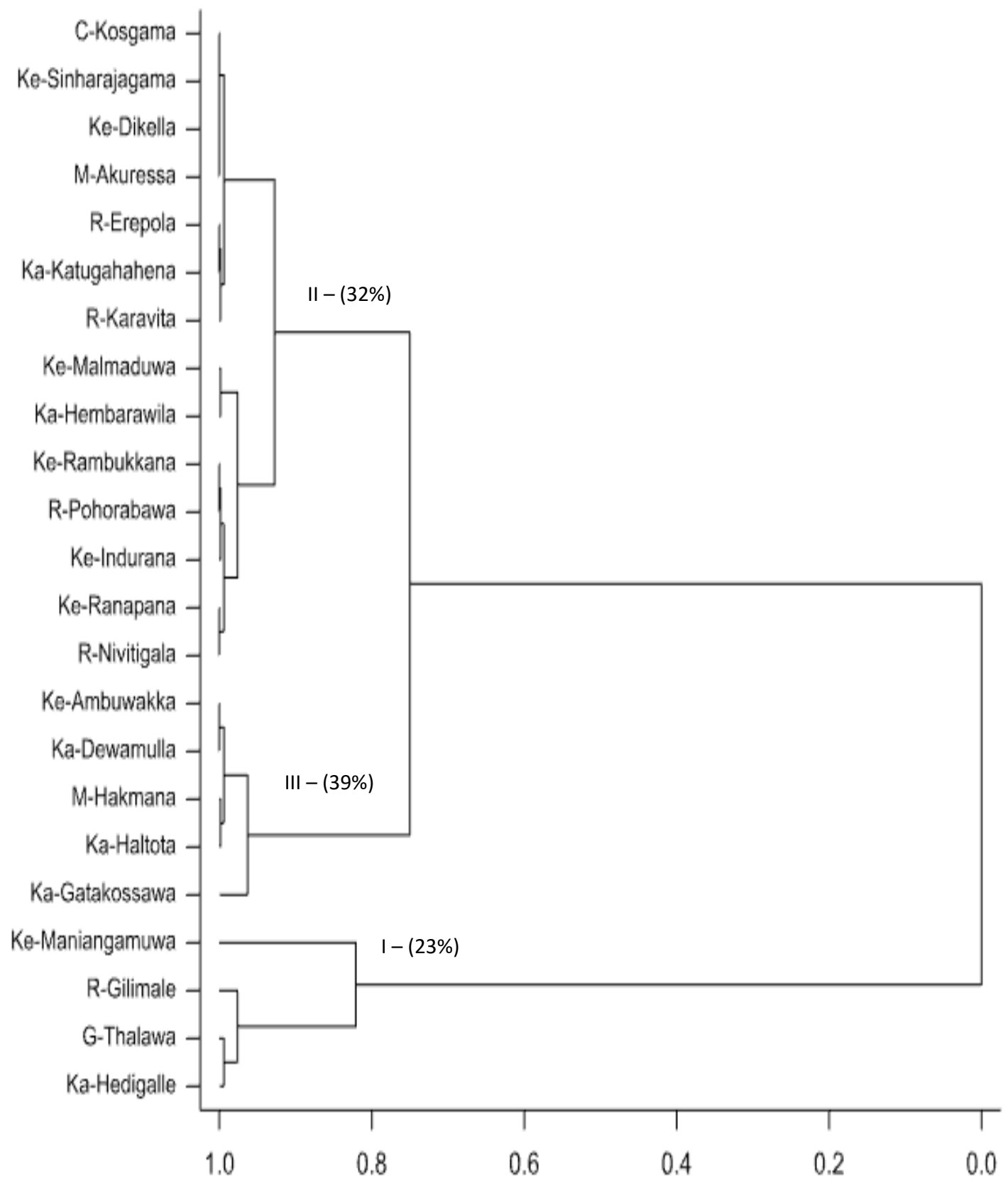

Figure 4. Dendrogram showing successive fusion of villages based on awareness on processing-related activities 
Table 8. Priorities identified through awareness tests for technology transfer in traditional rubber growing areas

\begin{tabular}{|c|c|c|c|c|c|}
\hline \multirow{2}{*}{ District } & \multirow{2}{*}{ DS division } & \multirow{2}{*}{ Village } & \multicolumn{3}{|c|}{ Priority } \\
\hline & & & Agronomy & Tapping & Processing \\
\hline Colombo & Kosgama & Kosgama & 1 & 1 & 2 \\
\hline \multirow[t]{8}{*}{ Kegalle } & Mawanella & Sinharajagama & 3 & 2 & 2 \\
\hline & Warakapola & Malmaduwa & 3 & 3 & 2 \\
\hline & Rambukkana & Rambukkana & 3 & 3 & 2 \\
\hline & Yatiyantota & Ambuwakka & 3 & 2 & 3 \\
\hline & Warakapola & Ranapana & 2 & 2 & 2 \\
\hline & Ruwanwella & Indurana & 3 & 3 & 2 \\
\hline & Kegalle & Dikella & 2 & 3 & 2 \\
\hline & Dehiovita & Maniangamuwa & 1 & 1 & 1 \\
\hline \multirow[t]{5}{*}{ Ratnapura } & Ehaliyagoda & Erepola & 2 & 1 & 2 \\
\hline & Ratnapura & Gilimale & 3 & 2 & 1 \\
\hline & Nivitigala & Nivitigala & 3 & 2 & 2 \\
\hline & Kalawana & Karavita & 3 & 3 & 3 \\
\hline & Kuruvita & $\begin{array}{l}\text { Pahala- } \\
\text { pohorabawa }\end{array}$ & 2 & 2 & 2 \\
\hline Galle & Galle & Thalawa & 2 & 1 & 1 \\
\hline \multirow[t]{2}{*}{ Matara } & Akuressa & Akuressa & 3 & 1 & 2 \\
\hline & Hakmana & Hakmana & 2 & 2 & 3 \\
\hline \multirow[t]{6}{*}{ Kalutara } & Horana & Gatakossawa & 3 & 3 & 3 \\
\hline & Bulatsinhala & Dewamulla & 3 & 3 & 3 \\
\hline & Agalawatta & Hedigalle & 3 & 2 & 1 \\
\hline & Millaniya & Haltota & 3 & 3 & 3 \\
\hline & Matugama & Katugahahena & 2 & 2 & 2 \\
\hline & Kalutara & Hembarawila & 3 & 2 & 2 \\
\hline
\end{tabular}

*1=Highest priority, 2=Moderate priority, 3=Low priority

\section{Conclusion}

Awareness on agronomic recommendations in different study sites ranged from $28 \%$ to $62 \%$ with an average of $49 \%$. The overall awareness on agronomic operations and tapping-related activities were somewhat similar with $49 \%$ and $50 \%$, respectively. Yet, the overall awareness on processing aspects was poor with an average awareness of 32 \%. The smallholders in the DS division Dehiovita were relatively poor with respect to awareness on the recommendations on agronomic, tapping and processing aspects. Hence, in this DS division, all three 
aspects should be given highest priority in awareness programmes. The DS division, Kosgama in the Colombo district needs to be given the highest priority in technology transfer on both agronomic and tapping-related activities. The DS division Galle also reported poor awareness on tapping and processing-related activities. Among the other locations, the highest priority for tapping-related technology transfer activities should be given for Eheliyagoda and Akuressa DS divisions in Ratnapura and Matara districts, respectively. Awareness on processing was poor in Ratnapura and Agalawatta DS divisions in Ratnapura and Kalutara districts, which need priority actions in technology transfer on processing aspects.

\section{Acknowledgement}

The extension officers of the ASD at RRISL in the districts who helped in facilitation and organization of workshops are gratefully acknowledged. A sincere appreciation is extended to smallholder farmers for their unreserved support given in the participatory studies.

\section{References}

Anonymous (2012): Statistical information on plantation crops. Ministry of Plantation Industries, Colombo, Sri Lanka.

Dissanayake, D.M.A.P. (2009): Strategies for efficient technology transfer in the smallholder sector. pp. 40-43. Proceedings of the Centennial Rubber Conference Sri Lanka 2009, 12-13 May, Colombo, Sri Lanka.

Rencher, A.C. (2002): Methods of Multivariate Analysis. $2^{\text {nd }}$ Edition. New York, USA: John Wiley and Sons.

Wijesuriya, B.W., Dissanayake, D.M.A.P., Herath, H.M.L.K., Wijeratne, M., Gunarathne, P.K.K.S., and Abeywardene, V. (2010): Priorities for technology transfer in nontraditional rubber growing areas in Sri Lanka. In: Proceedings of the third symposium on plantation Crop Research - Stakeholder empowerment through technological advance (Eds. Dharmakeerthi R.S. and Senevirathna, W.M.P.K.). pp. 299-310. Rubber Research Institute of Sri Lanka, Dartonfield, Agalawatta, Sri Lanka.

Wijesuriya, W., Dharmadasa, M, Ratnayaka, S., Abeydissanayake, D.R.A.M.G. and Chandrasiri, J.A.S. (2005). Level of awareness on recommended practices in rubber smallholdings in the Moneragala district. Bull. Rubber Res. Inst. Sri Lanka, 46: 44-51.

Wijesuriya, W., Dissanayake, D.M.A.P., Herath, K., Edirisinghe, J., Wijeratne, M. and Abeywardene, V. (2006).: Possible causes of low rubber yields in smallholder units in Sri Lanka. Natural Rubber Research, 19(1\&2): 25-37.

Wijesuriya, W., Dissanayake, D.M.A.P., Herath, K., Edirisinghe, J., and Abeywardene, V. (2007): Some issues related to sustainability in the smallholder rubber sector: a 
Dissanayake et al.

case study of three major rubber growing districts. J. Rubber Res. Inst. Sri Lanka, 88: 59-76.

Wijesuriya, W., Dissanayake, A., Samarappuli, L., Wijeratne, M., Gunaratne, K. and Abeywardene, V. (2008): Issues and perspectives of smallholder rubber farmers and possible solutions for sustainable rubber farming in non-traditional rubber growing areas. p. 247-256. Proc. $2^{\text {nd }}$ Symposium on Plantation Crop Research, 16-17 Oct., Colombo, Sri Lanka 